\title{
The impact of perceived social support on perception of health status in Isparta
}

\author{
Begüm CEYLAN ${ }^{1}$, Ramazan ERDEM ${ }^{2}$
}

\begin{tabular}{|c|c|}
\hline & ABSTRACT \\
\hline $\begin{array}{r}\text { Corresponding Author } \\
\text { Begüm CEYLAN } \\
\text { DoI } \\
\text { https://10.48121/jihsam.887541 } \\
\text { Received } \\
26.02 .2021 \\
\text { Accepted } \\
\text { 07.04.2021 } \\
\text { Published Online } \\
30.04 .2021\end{array}$ & $\begin{array}{l}\text { The aim of this study is to determine whether the level of } \\
\text { social support perceived in Isparta province has an effect } \\
\text { on health perception. Individuals over the age of } 18 \text { in the } \\
\text { city center of Isparta constitute the target population of the } \\
\text { research. } 399 \text { people were included in the research. The } \\
\text { Multidimensional Scale of Perceived Social Support } \\
\text { (MSPSS) developed by Zimet et al. (1988) and adapted into } \\
\text { Turkish by Eker and Arkar (1995) and The Perception of } \\
\text { Health Scale (PHS), developed by Diamond et al. (2007) } \\
\text { and adapted into Turkish by Kadioglu and Ylldiz (2012) } \\
\text { were used as a data tool in research. The analysis of the } \\
\text { data obtained was performed with the help of SPSS } \\
\text { program, frequency, percentage, mean, correlation and } \\
\text { regression analysis. Social support perception of the } \\
\text { participants is above the midpoint. Social support } \\
\text { perception dimensions are above the midpoint of } 3 \text {. It } \\
\text { emerged that the vast majority of participants received } \\
\text { support from their families. Among the dimensions of the } \\
\text { health perception scale, perceptions of the importance of } \\
\text { Health and dimensions of self-awareness are above } 3 \text {. It } \\
\text { was understood that participants thought about their } \\
\text { health, cared about them, and thought that whether they } \\
\text { were healthy or not was due to them. While there is a } \\
\text { significant and positive relationship between the } \\
\text { perception of caring for the health of participants receiving } \\
\text { support from a special person, there is a strong, } \\
\text { significant, and positive relationship between the } \\
\text { importance of caring for their health of participants } \\
\text { receiving supportfrom their family. }\end{array}$ \\
\hline
\end{tabular}

\footnotetext{
${ }^{1}$ Health Institutions Business Administration Programme, İzmir Kavram Vocational School, İzmir. begum.ceylan@kavram.edu.tr. Orcid: 00000002-3153-1010

Healthcare Management, Faculty of Economics and Administrative Sciences, Süleyman Demirel University, Isparta. raerdem@yahoo.com Orcid: 0000-0001-6951-3814
} 


\section{INTRODUCTION}

WHO defines health as "not only the absence of illness or disability, but a state of complete physical, mental and social well-being" (www.who.int). It is known that psychosocial variables such as beliefs and attitudes contribute to the health status of patients while explaining the concept of health. Various conceptual models have been designed to help explain how differences in health behaviors affect health status. Health Belief Model, Reasoning Theory and Social Learning Theory are examples of these models. (Diamond et al., 2007: 557).

Health perception is widely used in determining health status (Doğanay and Uçku, 2012: 396). Perceived health status assessments are an overall assessment of one's own health status (Idler and Benyamini, 97: 21). This assessment is known as a simple but powerful indicator that reflects the multidimensionality of health and enables the individual to evaluate his / her biological, mental and social situation. In addition, negative life events that emphasize the spiritual and social aspects of Health, unhappiness, depression, work problems, life satisfaction, social isolation, perceived stress and recent health status are known to be associated with perceived health (Kaplan and Camacho, 1983: 292).
Research across disciplines and societies reveals possible psychosocial mechanisms that explain how social bonds promote health (Umberson and Montez, 2010: 56). Based on this, social support may be related to the perception of health.

Social support refers to emotionally ongoing qualities of relationships (for example, a sense that a person is loved, cared for and listened to). Social support can have indirect effects on health by increasing mental health, reducing the impact of stress, or enhancing sense of meaning and purpose in life. Personal control refers to the beliefs of individuals that they can control life outcomes through their own actions. Social bonds can improve personal control (perhaps through social support), and in turn, personal control is advantageous for health habits, mental health, and physical health (Umberson and Montez, 2010: 56). It is also known that when we need to cope with stress and difficulties, we often turn to family, friends and someone special for help (Goldsmith, 2004: 1).

Since it is believed that social support may be related to health perception, this study was conducted to determine whether the level of social support has an impact on health perception.

\section{MATERIALS AND METHODS}

The universe of the study investigating the effect of perceived social support level on health perception in Isparta is composed of individuals aged 18 and over living in Isparta. In the research, 399 people were involved by using convenience sampling method.

The Multidimensional Scale of Perceived Social Support (MSPSS) consisting of 12 expressions developed by Zimet et al. (1988) and adapted into Turkish by Eker and Arkar (1995) and The Perception of Health Scale (PHS), which consists of 15 expressions developed by Diamond et al. (2007) and adapted into Turkish by Kadıoğlu and Yıldız (2012) were used as a data tool in research. Analysis of the data obtained using the SPSS program, frequency, percentile, mean, correlation and regression analyses were performed. The data were subjected to normality testing and it was determined that it showed normal distribution by looking at skewness and kurtosis coefficients.

Perception of Health Scale is a five-point Likert type scale consisting of 15 items and four sub-factors. Articles 1, 5, 9, 10, 11 and 14 are positive attitude, and Articles 2, 3, 4, 6, 7, 8, 12, 13 and 15 are negative statements. Positive statements were scored as "strongly agree $=5 "$ ", "agree $=4 "$ ", "Neutral $=3 "$, "disagree $=2$ ", "strongly disagree $=1 "$ ". Negative statements are scored in reverse form.

The Multidimensional Scale of Perceived Social Support (MSPSS) is a scale consisting of 12 items. It includes 3 groups related to the source of support, each consisting of 4 items. These are family (Articles 3, 4, 8, and 11), friends (Articles 6, 7, 9, and 12), and a special person. (Articles 1, 2, 5, and 10). 


\section{RESULTS}

\section{Demographic Findings}

The distribution of the participants in the study by demographic variables is shown in Table 1.

Table 1. Demographic Findings

\begin{tabular}{|c|c|c|}
\hline & Frequency & $\begin{array}{c}\text { Valid } \\
\text { Percent }\end{array}$ \\
\hline \multicolumn{3}{|l|}{ Age (Year) } \\
\hline $18-24$ & 123 & 30.8 \\
\hline $25-34$ & 127 & 31.8 \\
\hline $35-44$ & 81 & 20.3 \\
\hline $45+$ & 68 & 17.0 \\
\hline \multicolumn{3}{|l|}{ Gender } \\
\hline Men & 155 & 38.8 \\
\hline Woman & 244 & 61.2 \\
\hline \multicolumn{3}{|l|}{ Graduation } \\
\hline Primary Education & 28 & 7.0 \\
\hline High School & 52 & 13.0 \\
\hline Vocational School & 51 & 12.8 \\
\hline University & 230 & 57.6 \\
\hline Postgraduate & 38 & 9.5 \\
\hline \multicolumn{3}{|l|}{ Marital Status } \\
\hline Married & 187 & 46.9 \\
\hline Single & 195 & 48.9 \\
\hline Other & 17 & 4.3 \\
\hline \multicolumn{3}{|c|}{ Chronic Disease State } \\
\hline None & 336 & 84.2 \\
\hline $\mathrm{Be}$ & 63 & 15.8 \\
\hline \multicolumn{3}{|l|}{ Gelir Düzeyi } \\
\hline $200-2000$ & 88 & 40.9 \\
\hline $2001-4000$ & 47 & 21.9 \\
\hline $4001+$ & 80 & 37.2 \\
\hline Total & 399 & 100.0 \\
\hline
\end{tabular}

As can be seen in Table 1, 30.8\% of the people participating in the study are in the 18-24 age range, $31.8 \%$ in the $24-34$ age range, $20.3 \%$ in the $35-44$ age range, and $17 \%$ are over the age of 45 . While $38.8 \%$ of the participants are male, $61.2 \%$ are female. Considering their marital status, it is seen that $46.9 \%$ of them are married and $48.9 \%$ are single.

When the educational status of the participants is examined, it is found that $7 \%$ are primary school graduates, $13 \%$ are high school graduates, $12.8 \%$ are associate degree graduates, $57.6 \%$ are undergraduates and $9.5 \%$ have postgraduate education.

When the income status of the participants is examined, it is seen that $40 \%$ of their income is between 200-2000 TL and below, $21.9 \%$ of them is between $2001-4000 \mathrm{TL}$ and $37.2 \%$ of them is $4000 \mathrm{TL}$ and above.

Finally, more than half $(84.2 \%)$ of the respondents do not have a chronic condition.

\section{Findings Related to Perceptions of Social Support}

Table 2. Distribution of the Points of Participants Received from the Expressions Related to Social Support Perceptions

\begin{tabular}{|r|r|c|c|}
\hline No & MSPSS Items & $\bar{X}$ & SS \\
\hline 1 & $\begin{array}{r}\text { There is a special person who is } \\
\text { around when I am in need. }\end{array}$ & 4.09 & 1.155 \\
\hline 2 & $\begin{array}{r}\text { There is a special person with whom I } \\
\text { can share my joys and sorrows. }\end{array}$ & 4.15 & 1.129 \\
\hline 3 & My family really tries to help me. & 4.35 & 0.951 \\
\hline 4 & $\begin{array}{r}\text { I get the emotional help and support I } \\
\text { need from my family. }\end{array}$ & 4.18 & 1.099 \\
\hline 5 & $\begin{array}{r}\text { I have a special person who is a real } \\
\text { source of comfort to me. }\end{array}$ & 3.99 & 1.274 \\
\hline 6 & My friends really try to help me. & 3.93 & 1.019 \\
\hline 7 & $\begin{array}{r}\text { I can count on my friends when } \\
\text { things go wrong. }\end{array}$ & 3.79 & 1.114 \\
\hline 8 & $\begin{array}{r}\text { I can talk about my problems with my } \\
\text { family. }\end{array}$ & 3.97 & 1.169 \\
\hline 9 & $\begin{array}{r}\text { I have friends with whom I can share } \\
\text { my joys and sorrows. }\end{array}$ & 4.15 & 0.948 \\
\hline 10 & $\begin{array}{r}\text { There is a special person in my life } \\
\text { who cares about my feelings. }\end{array}$ & 3.99 & 1.279 \\
\hline 11 & $\begin{array}{r}\text { My family is willing to help me make } \\
\text { decisions. }\end{array}$ & 4.17 & 1.090 \\
\hline 12 & $\begin{array}{r}\text { I can talk about my problems with my } \\
\text { friends. }\end{array}$ & 4.05 & 1.004 \\
\hline
\end{tabular}

Table 2 shows the arithmetic mean and standard deviation distributions of the Social Support Perception expressions. When the table is examined, it is seen that 12 expressions in the questionnaire have a value above Questions 3, 1, 2, 5, 10 include perceived support from a particular person. Accordingly, the participants seem to perceive that there is a special person when needed (4.09), a special person with whom joys and sorrows can be shared (4.15), a special person who relieves (3.99), and a special person who cares about his feelings (3.99).

Questions 3, 4, 8, 11 include the perceived support received from the family. It is revealed that the participants think that their family is helpful (4.35), that they receive emotional help and support from the family (4.18), that they talk about their problems with their family (3.97), and that the family is willing to help when making decisions (4.17). Questions 6, 7, 9, 12 contain perceived support from a friend. Based on this, it is seen that the participants in the study think their friends were helpful (3.93), that they can trust their friends when things go wrong, that they can share their joys and sorrows with their friends (4.15), and that they can talk to their friends (4.05).

The expression "My family really tries to help me", which is in the first place among the Social Support Perception expressions (4.35), is the expression with the highest level of participation. The statement "I get the emotional help and support I need from my family" (4.18) ranks second and the statement "My family is willing to help me make 
decisions" (4.17) comes in 3rd place. Based on this, the fact that the social support received from the family has the highest values in three statements leads to the conclusion that the participants receive the most support from their families.

\section{Findings Related to Perceptions of Health}

Table 3. Distribution of the Scores the Participants Got from the Expressions Related to Health Perceptions

\begin{tabular}{|c|c|c|c|}
\hline No & $\begin{array}{r}\text { Items of the Perception of Health } \\
\text { Scale }\end{array}$ & $X$ & SS \\
\hline 1 & I think about my health a lot. & 3.80 & 1.013 \\
\hline 2 & $\begin{array}{r}\text { Being healthy is largely a matter of } \\
\text { good fortune. }\end{array}$ & 2.46 & 1.202 \\
\hline 3 & $\begin{array}{r}\text { No matter what I do, if I am going to } \\
\text { be healthy or not, it is just going to } \\
\text { happen. }\end{array}$ & 2.55 & 1.275 \\
\hline 4 & I is God's will if I am healthy. & 3.45 & 1.302 \\
\hline 5 & $\begin{array}{r}\text { If I exercise and eat right, I'm almost } \\
\text { certain to stay healthy. }\end{array}$ & 3.96 & 0.938 \\
\hline 6 & $\begin{array}{r}\text { I am often confused about what I } \\
\text { should do to stay healthy. }\end{array}$ & 2.75 & 1.198 \\
\hline 7 & $\begin{array}{l}\text { I would like to be healthier, but I just } \\
\text { can't get myself to do what necessary. }\end{array}$ & 3.23 & 1.282 \\
\hline 8 & $\begin{array}{l}\text { There are so many different reports on } \\
\text { kinds of foods that keep you healthy } \\
\text { that I don't know what I should do. }\end{array}$ & 2.77 & 1.175 \\
\hline 9 & $\begin{array}{l}\text { I'm willing to spend extra Money on } \\
\text { things that are healthy for me. }\end{array}$ & 3.46 & 1.131 \\
\hline 10 & $\begin{array}{r}\text { It is up to me whether I am healthy or } \\
\text { not. }\end{array}$ & 3.82 & 0.959 \\
\hline 11 & $\begin{array}{l}\text { My health is the most important } \\
\text { consideration in my life. }\end{array}$ & 3.72 & 1.043 \\
\hline 12 & Good health is a matter of good luck. & 2.40 & 1.136 \\
\hline 13 & $\begin{array}{r}\text { No matter what I do, I cannot change } \\
\text { how healthy I am. }\end{array}$ & 2.24 & 1.197 \\
\hline 14 & I can be as healthy as I desire. & 3.22 & 1.101 \\
\hline 15 & $\begin{array}{r}\text { I cannot understand everything I read } \\
\text { about healthy eating. }\end{array}$ & 2.48 & 1.160 \\
\hline
\end{tabular}

The arithmetic mean and standard deviation distributions of Perception of Health expressions are given in Table 3 . The scores were reversed because the statements $2,3,4,6,7,8,12,13,15$ were reverse scored questions. The statement "Being healthy is largely a matter of good fortune." got (2.46) points. It is thought that the participants do not see being healthy as a matter of luck. The statement "No matter what I do, if I am going to be healthy or not, it is just going to happen." has received (2.55) points. Participants believe that their state of being sick or healthy is under the control of the person. The statement "I am often confused about what I should do to stay healthy." got (2.75) points. Participants are not confused about what they should do to stay healthy. The statement " There are so many different reports on kinds of foods that keep you healthy that I don't know what I should do." got a score of (2.77) points. Participants know what to do about the types of food that protect health. The statement " Good health is a matter of good luck." got (2.40) points. Participants do not see being healthy as a chance. "No matter what I do, I cannot change how healthy I am." statement received (2.24) points. Participants think they can change their health status. The statement "I cannot understand everything I read about healthy eating" got a score of (2.48). It can be concluded that the participants understand what they read about healthy eating.

The expression " If I exercise and eat right, I'm almost certain to stay healthy" (3.96), which is in the first place among the expressions of Perception of Health, is the expression with the highest level of participation. Most of the participants think that if they exercise and eat right, they will stay healthy.

\section{Psychometric Properties Of Dimensions}

Social support perception and psychometric properties of Health perception

In the study, participants ' perception of social support was evaluated within the framework of 3 and health perception was evaluated within 4 groups, and the values received by each group were shown in Table 4.

Table 4. Psychometric Properties of Perception of Social Support and Perception of Health

\begin{tabular}{|c|c|c|c|c|c|c|c|c|}
\hline & \multirow{2}{*}{$\begin{array}{l}\text { Number } \\
\text { of Items }\end{array}$} & \multirow{2}{*}{$\begin{array}{l}\text { Min- } \\
\text { Max }\end{array}$} & \multirow[b]{2}{*}{$\bar{X}$} & \multirow[b]{2}{*}{ SS } & \multirow{2}{*}{$\begin{array}{c}\text { Cronbach } \\
\text { Alfa }\end{array}$} & & \\
\hline & & & & & & & Skewness & Kurtotis \\
\hline \multirow{3}{*}{$\begin{array}{l}\text { Perceived } \\
\text { Social } \\
\text { Support }\end{array}$} & Family & 4 & $1-5$ & 4.164 & 0.952 & 0.905 & -1.317 & 0.853 \\
\hline & Significant Other & 4 & $1-5$ & 4.055 & 1.101 & 0.930 & -1.168 & 0.372 \\
\hline & Friends & 4 & $1-5$ & 3.981 & 0.885 & 0.888 & -0.742 & -0.193 \\
\hline \multirow{4}{*}{$\begin{array}{l}\text { Perception } \\
\text { of Health }\end{array}$} & Center of Control & 5 & $1-5$ & 2.617 & 0.877 & 0.763 & 0.373 & -0.310 \\
\hline & Certainty & 4 & $1-5$ & 2.805 & 0.856 & 0.674 & 0.169 & -0.218 \\
\hline & $\begin{array}{l}\text { Importance of } \\
\text { Health }\end{array}$ & 3 & $1-5$ & 3.660 & 0.797 & 0.611 & -0.592 & 0.232 \\
\hline & Self-Awereness & 3 & $1-5$ & 3.665 & 0.718 & 0.527 & -0.289 & 0.041 \\
\hline
\end{tabular}

The kurtosis and skewness values of each dimension were found by examining whether the data showed normal distribution and it was determined that the values remained between 1.96 and +1.96 . Therefore, it is concluded that the data show a normal distribution (Can, 2014: 85). It does not interfere with parametric testing.

Information on the subgroups of each perceived social support shown in Table 4 is given below: 
Perceived Support from the Family: This group consists of 4 statements. Each statement expresses the perceived support that the participants receive from the family. Its arithmetic mean was 4.164 and its standard deviation was 0.952. The Cronbach Alpha was found to be reliable as 0.905 .

Perceived Support from a Significant Other: This group consists of 4 statements. Each statement expresses the perceived support the participants get from a special person. Its arithmetic mean was 4.055 and its standard deviation was 1.101. The Cronbach Alpha was found to be reliable as 0.930 .

Perceived Support from Friends: This group consists of 4 statements. Each statement expresses the perceived support the participants get from their friends. Its arithmetic mean was 3.981 and its standard deviation was 0.885 . The Cronbach Alpha was found to be reliable as 0.888 .

Information on perception of health sub-groups shown in Table 4 are given below:

Center of Control: This group consists of 5 statements. Expressions in this dimension are inverse.
Each statement expresses the control over whether the participants are healthy or not. Its arithmetic mean was 2.617 and its standard deviation was 0.877. The Cronbach Alpha was found to be 0.763 as reliable.

Certainty: This group consists of 4 statements. Expressions in this dimension are inverse. Each statement expresses the certainty about whether the participants are healthy. Its arithmetic mean was 2.805 and its standard deviation was 0.856 . The Cronbach Alpha was found to be 0.674 as reliable.

Importance of Health: This group consists of 3 statements. Each statement expresses the importance that the participants attach to their health. Its arithmetic mean was 3.660 and its standard deviation was 0.797 . The Cronbach Alpha was found to be 0.611 as reliable.

Self-Awareness: This group consists of 3 statements. Each statement expresses self-awareness of participants' well-being. Its arithmetic mean was 3.665 and its standard deviation was 0.718 . The Cronbach Alpha was found to be 0.527 , which was low in terms of reliability.

Table 5. The Relationship Between Perception of Social Support and Perception of Health

\begin{tabular}{|c|c|c|c|c|c|c|c|c|}
\hline & & \multicolumn{3}{|c|}{ Perceived Social Support } & \multicolumn{4}{|c|}{ Perception of Health } \\
\hline & & Family & $\begin{array}{l}\text { Significant } \\
\text { Other }\end{array}$ & Friends & $\begin{array}{l}\text { Center of } \\
\text { Control }\end{array}$ & Certainty & $\begin{array}{l}\text { Importance } \\
\text { of Health }\end{array}$ & $\begin{array}{l}\text { Self- } \\
\text { Awareness }\end{array}$ \\
\hline \multirow{3}{*}{ 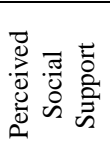 } & Family & 1 & & & & & & \\
\hline & $\begin{array}{l}\text { Significant } \\
\text { Other }\end{array}$ & $\begin{array}{l}\mathrm{r}=0.372 * * \\
\mathrm{p}=0.000 * * *\end{array}$ & 1 & & & & & \\
\hline & Friends & $\begin{array}{l}\mathrm{r}=0.464 * * \\
\mathrm{p}=0.000^{* * *}\end{array}$ & $\begin{array}{l}\mathrm{r}=0.338 * * \\
\mathrm{p}=0.000 * * *\end{array}$ & 1 & & & & \\
\hline \multirow{4}{*}{ 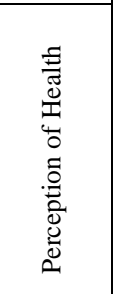 } & $\begin{array}{l}\text { Center of } \\
\text { Control }\end{array}$ & $\begin{array}{l}r=0.001 \\
p=0.983\end{array}$ & $\begin{array}{l}r=-0.005 \\
p=0.924\end{array}$ & $\begin{array}{l}\mathrm{r}=-0.048 \\
\mathrm{p}=0.336\end{array}$ & 1 & & & \\
\hline & Certainty & $\begin{array}{l}\mathrm{r}=-0.029 \\
\mathrm{p}=0.561\end{array}$ & $\begin{array}{l}r=-0.44 \\
p=0.378\end{array}$ & $\begin{array}{l}\mathrm{r}=-0.087 \\
\mathrm{p}=0.083^{*}\end{array}$ & $\begin{array}{l}\mathrm{r}=0.506 * * \\
\mathrm{p}=0.000^{* * *}\end{array}$ & 1 & & \\
\hline & $\begin{array}{l}\text { Importance } \\
\text { of Health }\end{array}$ & $\begin{array}{l}\mathrm{r}=0.138^{* *} * \\
\mathrm{p}=0.006 * *\end{array}$ & $\begin{array}{l}\mathrm{r}=0.119^{*} \\
\mathrm{p}=0.018^{*}\end{array}$ & $\begin{array}{l}\mathrm{r}=0.059 \\
\mathrm{p}=0.243\end{array}$ & $\begin{array}{l}r=-0.068 \\
p=0.176\end{array}$ & $\begin{array}{l}r=-0.019 \\
p=0.704\end{array}$ & 1 & \\
\hline & $\begin{array}{l}\text { Self- } \\
\text { Awareness }\end{array}$ & $\begin{array}{l}r=0.040 \\
p=0.429\end{array}$ & $\begin{array}{l}r=0.082 \\
p=0.103\end{array}$ & $\begin{array}{l}\mathrm{r}=0.045 \\
\mathrm{p}=0.372\end{array}$ & $\begin{array}{l}\mathrm{r}=-0.180 * * \\
\mathrm{p}=0.000 * * *\end{array}$ & $\begin{array}{l}r=-0.048 \\
p=0.340\end{array}$ & $\begin{array}{l}\mathrm{r}=0.349 * * \\
\mathrm{p}=0.000 * * *\end{array}$ & 1 \\
\hline
\end{tabular}

The relationships between the sub-dimensions of the social support perception scale and the sub-dimensions of the health perception scale are included in Table 5. When the correlations between perception of social support subdimensions and perception of health sub-dimensions are examined, There is a positive relationship between the importance of health dimension, which is the sub-dimension of health perception, and the dimension of support from a special person $(r=0.119, p=0.018)$, which is the sub-dimension of social support. There is a strong positive relationship between the family support dimension $(\mathrm{r}=0.138, \mathrm{p}=0.006)$. While there is a significant and positive relationship between the importance of health care of the participants who receive support from a special person, it is seen that there is a strong, significant and positive relationship between the participants who receive support from their families paying attention to their health.

\begin{tabular}{|c|c|c|c|c|c|c|c|c|}
\hline $\begin{array}{l}\text { Independent } \\
\text { Variable }\end{array}$ & $\begin{array}{c}\text { Dependent } \\
\text { Variable }\end{array}$ & $\mathrm{R}$ & $\mathrm{R}^{2}$ & $\mathrm{~F}$ & $\mathrm{p}$ & B & $\mathrm{t}$ & $\mathrm{p}$ \\
\hline Family & \multirow{3}{*}{$\begin{array}{l}\text { Center of } \\
\text { Control }\end{array}$} & \multirow[t]{3}{*}{0.055} & \multirow[t]{3}{*}{0.003} & \multirow[t]{3}{*}{0.405} & \multirow[t]{3}{*}{0.750} & 0.028 & 0.480 & 0.631 \\
\hline $\begin{array}{l}\text { Significant } \\
\text { Other }\end{array}$ & & & & & & 0.006 & 0.112 & 0.911 \\
\hline Friends & & & & & & -0.063 & -1.096 & 0.274 \\
\hline
\end{tabular}


As a result of the regression analysis, $0.3 \%\left(\mathrm{R}^{2}=0.003\right)$ of the change in the control center variable is explained by independent variables (family support, support from someone special, support of friends). In addition, it is seen that the explanatory power of the model has a positive effect but is not statistically significant $(\mathrm{F}=0.405, \mathrm{p}=0.750)$.

\begin{tabular}{|c|c|c|c|c|c|c|c|c|}
\hline $\begin{array}{c}\text { Independent } \\
\text { Variable }\end{array}$ & $\begin{array}{c}\text { Dependent } \\
\text { Variable }\end{array}$ & $\mathrm{R}$ & $\mathrm{R}^{2}$ & $\mathrm{~F}$ & $\mathrm{p}$ & $\beta$ & $\mathrm{t}$ & $\mathrm{p}$ \\
\hline Family & \multirow{3}{*}{ Certainty } & \multirow[t]{3}{*}{0.090} & \multirow[t]{3}{*}{0.008} & \multirow[t]{3}{*}{1.075} & \multirow[t]{3}{*}{0.359} & 0.020 & 0.344 & 0.731 \\
\hline $\begin{array}{l}\text { Significant } \\
\text { Other }\end{array}$ & & & & & & -0.022 & -0.393 & 0.694 \\
\hline Friends & & & & & & -0.089 & -1.540 & 0.124 \\
\hline
\end{tabular}

As a result of the regression analysis, $0.8 \%\left(\mathrm{R}^{2}=0.008\right)$ of the change in the precision variable is explained by the independent variables (family support, support from someone special, support from friends). In addition, it is seen that the explanatory power of the model has a positive effect but is not statistically significant. $(\mathrm{F}=1.075$, $\mathrm{p}=0.359)$

\begin{tabular}{|c|c|c|c|c|c|c|c|c|}
\hline $\begin{array}{c}\text { Independent } \\
\text { Variable }\end{array}$ & $\begin{array}{c}\text { Dependent } \\
\text { Variable }\end{array}$ & $\mathrm{R}$ & $\mathrm{R}^{2}$ & $\mathrm{~F}$ & $\mathrm{p}$ & $\beta$ & $\mathrm{t}$ & $\mathrm{p}$ \\
\hline Family & \multirow{3}{*}{$\begin{array}{c}\text { Importance } \\
\text { of Health }\end{array}$} & \multirow[t]{3}{*}{0.157} & \multirow[t]{3}{*}{0.025} & \multirow[t]{3}{*}{3.335} & \multirow[t]{3}{*}{$0.019 *$} & 0.118 & 2.038 & 0.042 \\
\hline $\begin{array}{c}\text { Significant } \\
\text { Other }\end{array}$ & & & & & & 0.083 & 1.516 & 0.130 \\
\hline Friends & & & & & & -0.024 & -0.425 & 0.671 \\
\hline
\end{tabular}

As a result of regression analysis, $2.5 \%$ of the change in the value of Health variable $(\mathrm{R} 2=0.025)$ is explained by independent variables (family support, support from someone special, support from friends). In addition, it is seen that there is no problem in terms of the explanatory power of the model $(\mathrm{F}=3.335, \mathrm{p}=0.019)$. The result was found statistically significant.

Family support $(\beta=0.224, \mathrm{t}=2.861, \mathrm{p}=0.005)$ dimension is found to have a positive effect on the importance of health and this effect was statistically significant. It has been observed that people who receive support from their families attach more importance to their health.

\begin{tabular}{|c|c|c|c|c|c|c|c|c|}
\hline $\begin{array}{c}\text { Independent } \\
\text { Variable }\end{array}$ & $\begin{array}{c}\text { Dependent } \\
\text { Variable }\end{array}$ & $\mathrm{R}$ & $\mathrm{R}^{2}$ & $\mathrm{~F}$ & $\mathrm{p}$ & $\beta$ & $\mathrm{t}$ & $\mathrm{p}$ \\
\hline Family & \multirow{3}{*}{$\begin{array}{c}\text { Self- } \\
\text { Awareness }\end{array}$} & \multirow[t]{3}{*}{0.084} & \multirow[t]{3}{*}{0.007} & \multirow[t]{3}{*}{0.934} & \multirow[t]{3}{*}{0.424} & 0.004 & 0.063 & 0.949 \\
\hline $\begin{array}{l}\text { Significant } \\
\text { Other }\end{array}$ & & & & & & 0.074 & 1.350 & 0.178 \\
\hline Friends & & & & & & 0.018 & 0.310 & 0.757 \\
\hline
\end{tabular}

As a result of regression analysis, $0.07 \%$ of the change in self-awareness variable (R2=0.007) is explained by independent variables (family support, support from someone special, support from friends). It is also found that the explanatory power of the model has a positive effect, but is not statistically significant. $(\mathrm{F}=0.934, \mathrm{p}=0.424)$

\section{DISCUSSION}

Evren et al. (2011: 382) found statistically significant relationships between violent behavior and perceived health in their study. Accordingly, it was found that all students were more likely to perceive their health poorly in those who were subjected to violence, in those who were in a fight in the last 12 months, in those who did not attend school because they did not feel safe, and in those who attempted suicide than in students who did not engage in these behaviors. Efteli and Khorshtd (2016: 8) found that social activity level, income level, working in any job and being married affect the perception of health. Tuğut and Bekar (2008: 25) found that the health perception average of those who did not drink alcohol was high when analyzed according to the alcohol consumption of university students. According to the study of Altay et al. (2016: 188), elderly people with chronic diseases and living in nuclear families have higher perception of health. In this study, it is seen that there is a significant relationship between the participants who receive support from a private person and the participants who receive support from their family in attaching importance to their health. While it was observed that the participants who received support from their family and a special person gave importance to their health, it was observed that those who received support from their families gave more importance to their health.

As a result of the research conducted by Çaka et al. (2017: 202), it was observed that individuals with high perception of health also have higher self-confidence. In this study, they think that the participants think about their health, care about their health and whether they are healthy or not is due to themselves. 


\section{CONCLUSIONS}

Participants ' perception of social support is above the midpoint. Among the dimensions (friend, special person, family), it was concluded that they also received the most social support from the family dimension. Among the dimensions of the health perception scale (Control Center, certainty, importance of health, self-awareness), perceptions of the importance of Health and dimensions of selfawareness are above 3 . It is determined that the participants think about their health, care about their health, and whether they are healthy or not is due to themselves.

While there is a significant and positive relationship between the importance of health care of the participants who receive support from a special person, it is seen that there is a strong, significant and positive relationship between the participants who receive support from their families in paying attention to their health. Finally, it has been found that the size of family support from social support dimensions has a significant and positive effect on the importance of health from health perception dimensions. People who received support from their family were seen to place more emphasis on their health.

\section{Acknowledgments:}

This article abstract was presented at the 5 . International Health Sciences and Management Conference (IHMC) on Kırşehir in July. The author gratefully acknowledges the support provided by the International Strategic Health Research Center (USSAM).

\section{Conflict of Interest:}

To the best of our knowledge, the named authors have no conflict of interest, financial or otherwise.

\section{Ethical Approval (Must be answered):}

Ethics approval was not obtained for this study.

\section{Funding:}

I have not financial support

\section{REFERENCES}

Altay, B., Çavuşoğlu, F., ve Çal, A., (2016). "Yaşlıların Sağlık Algısı, Yaşam Kalitesi Ve Sağlıkla İlgili Yaşam Kalitesini Etkileyen Faktörler”, TAF Prev Med Bull, 15(3): 181-189.

Can, A., (2014), SPSS ile Bilimsel Araştırma Sürecinde Nicel Veri Analizi, 3. Baskı, Ankara: Pegem Akademi.

Caka, S. Y., Topal, S., Suzan, Ö. K., Çınar, N., ve Altınkaynak, S., (2017). "Hemşirelik Öğrencilerin Sağlı Algısı İle Özgüvenleri Arasındaki İlişki” J hum rhythm, 3(4): 199-203.

Diamond, J. J., Becker, J. A., Arenson, C. A., Chambers, C. V., and Rosenthal, M. P., (2007). "Development Of A Scale To Measure Adults Perceptions Of Health: Preliminary Finding", Journal of Community Psychology, 35(5): 557-561.

Doğanay, S., ve Uçku, Ş. R., (2012). "Yaşlılarda Kötü Sağlık Algısı Koroner Kalp Hastalığı ve Ölümleri Belirler mi ?" Turkish Journal of Geriatrics, 15(4): 396-402.

Efteli, E., ve Khorshtd, L., (2016). "İki Farklı Bölüm Öğrencilerinin Sağlık Algılarının Karşılaştırılması”, Ege Üniversitesi Hemşirelik Fakültesi Dergisi, 32 (2): 1-10.

Eker, D., ve Arkar, H., (1995). "Çok Boyutlu Algılanan Sosyal Destek Ölçeği'nin Faktör Yapısı, Geçerlik ve Güvenirliği”, Türk Psikoloji Dergisi, 10(34): 45-55.

Evren, H., Tokuç, B. ve Ekuklu, G., (2011). "Trakya Üniversitesi Öğrencilerinde Şiddet Davranışları ve Algılanan Sağlık İlişkisi”, Balkan Med J, 28: 380-384.
Goldsmith, D. J., (2004). (Ed.), Communicating Social Support, New York: Cambridge University Press.

https://www.who.int/about/who-we-are/frequently-asked questions\#: : text=What $\% 20$ is $\% 20$ the $\% 20 \mathrm{WHO} \% 20$ definition,abse nce $\% 20$ of\%20disease\%20or\%20infirmity Date: 01.07.2020

Idler, E, L., ve Benyamini, E., (1997). "Self-Rated Health and Mortality: A Review of Twenty-Seven Community Studies", Journal of Health and Social Behavior, 38(1): 21-37.

Kadıŏlu, H., ve Yıldız, A., (2012). "Sağlık Algısı Ölçeği’nin Türkçe Çevriminin Geçerlik ve Güvenirliliği”, Türkiye Klinikleri J Med Sci, 32(1): 47-53.

Kaplan, G. A., ve Camacho, T., (1983). "Perceived Health and Mortality: A Nine-Year Follow-Up of the Human Population Laboratory Cohort", American Journal of Epidemiology, 117(3): 292-304.

Tuğut, N., ve Bekar, M., (2008). “Üniversite Öğrencilerinin Sağlığı Alglama Durumları İle Sağlıklı Yaşam Biçimi Davranıșları Arasındaki İlişki”, Atatürk Üniversitesi Hemşirelik Yüksekokulu Dergisi, 11(3): 17-26.

Umberson, D., ve Montez, J. K., (2010). "Social Relationships and Health: A Flashpoint for Health Policy", Journal of Health and Social Behavior, 51(S): 54-66.

Zimet, G. D., Dahlem, N. W., Zimet, S. G., ve Farley, G. K., (1988). "The Multidimensional Scale of Perceived Social Support", Journal of Personality Assessment, 52(1): 30-41. 